\title{
The Collapse of Intermediate Structures?
}

Carl Milofsky, Bucknell University, Margaret Harris, Aston University (UK)

How can we explain the rise of President Trump and the attraction of his campaign behavior before and since he took office? We argue here that the collapse of 'intermediate structures' has been a key factor; that the associations and groups which are building blocks of pluralistic politics have been eroded to such an extent that Trump's personality politics have been able to take over the political stage.

Sustainable democracies require a layer of institutions situated between the realms of the state, on the one hand, and individuals and families, on the other. These are 'intermediate structures' and they are conduits for citizen participation and a bulwark against the formation of 'mass' societies in which political leaders and the states they govern can directly interact with citizens and control them ideologically. In the last century, such direct connection between states and citizens, which can happen as intermediate structures dissolve, was blamed for the emergence and domination of charismatic, authoritarian leaders.

We present evidence here that erosion of intermediate structures has indeed been taking place over recent decades and that the rise to power of Donald Trump is one outcome of that erosion. When intermediate structures collapse, politicians and citizens can impact directly on one another's behavior and viewpoints, without the leavening factor provided by the associations of civil society. 


\section{The Concept of Intermediate Structures}

The idea of 'intermediate structures' is found-with variations in terminology-in the work of many scholars. Broadly, they argue that sustainable democracies require a layer of institutions situated between the realms of the state, on the one hand, and the private sphere of individual citizens, on the other. Intermediate structures allow citizens to compete with other groups and to communicate their desires and needs upward in the governance system while receiving political information downward from political leaders. This participation serves as a bulwark against the formation of 'mass' societies in which states directly interact with, and ideologically control, citizens, even inducing them to ignore their own self-interests.

Kornhauser (1959), drawing on Durkheim's concept of "secondary institutions" (1958: 62-63), conceptualized intermediate structures as including the workplace and formal institutions like schools, churches and service providers. He saw their importance as lying in the way in which they linked into a web of informal groups and networks that provide individuals with a sense of responsibility, accountability, agency, and identity. Where such intermediate structures are eroded or poorly developed, anti-democratic forces at the state level can flourish.

In similar vein, Warner and Lunt (1942) identified 'primary institutions' such as the economy, schools, the legal system or health care and contrasted them with 'secondary associations' that are the means through which primary systems are linked. What they called secondary associations were what we might now refer to as 'voluntary associations'. People involved in such associations are 
likely to belong to different primary institutions but by forging informal ties with people who have different formal institutional connections, crosscutting networks or matrices of societal relationships are formed. These help to prevent people from adopting politically extreme values (Coser 1956; Simmel 1955). They provide social cohesion and encourage participants to interpret activities of the primary institutions in ways that provide personal meaning.

That such matrices exist is core to the concept of 'social capital' as Coleman (1994) developed it. He used that concept to explain why low-income Catholic school children, immersed in informal ties, learned better than lowincome students in public schools where the social networks tended to be individualistic and sterile.

More recently Putnam (2000; 2015) has referred to the decline of what he has termed 'voluntary associations' but he appears to be referring quite broadly to the whole realm of intermediate structures that tie people to communities of participation in the non-governmental, non-market sphere.

Based on this long tradition in the sociological literature, we can see 'intermediate structures' as including not only the economy but also social service institutions in which professionals are embedded and what Warren (1967) termed 'community decision organizations'. Intermediate structures also include local communities, local associations, religious congregations and local political movements. In fact, all organizations that enable individual participation and draw together citizens are crucial to the strength of the intermediate layer. They are the building blocks of networks of overlapping relationships for individuals, they foster trust and symbolic meaning, and they facilitate identity formation. 
Where intermediate institutions are weak or deliberately eroded by governments aspiring to interact directly with individual citizens, democracy is threatened.

\section{Erosion of Intermediate Structures}

Empirical and theoretical scholarship suggests two ways in which the intermediate structures might be threatened or eroded.

One threat has to do with 'political elites' and whether in practice they pay attention to individual citizens and the intermediary layer of participatory organizations. Theorists of democracy in political science see society as 'pluralistic' with diverse demands, pressures, and information coming from citizens and interest groups. In this scenario, politicians seeking votes become mediators, balancing competing demands and devising politically acceptable solutions (Meyerson and Banfield 1955). But what if elites decide not to respond to the assemblage of pluralist interest groups-a possibility envisioned by Dahl and Lindblom (1953: 227-271) and more recently by Aronowitz (1996)? Using his case study of the AIDS activist organization ACT-UP, Aronowitz argues that in the current era of the liberal state, electorates and governments themselves respond only to 'disruptive" politics. Political elites operate largely independently of the electorate or pressure groups and respond only to economic or populist power.

A second possible threat has been famously pinpointed by Putnam (2000; also see Silva, 2013) who used empirical research findings to suggest that there has been a major decline in participatory organizations (or 'voluntary associations', typified by 'bowling leagues'), which link individuals into 
communities of place or common interest. The concern here is that once individuals are cut loose from these community ties and their potentially moderating influences, they are susceptible to 'extreme' explanations for societal ills and populist appeals from politicians.

Essentially, this is part of a larger argument about the decline of 'civil society'. Civil society theorists posit that the vitality of the pluralist political system depends on a matrix of voluntary associations and other intermediate structures (Cohen and Arato 1994; Edwards, 2014; Fung 2003). Where citizens belong to a variety of such intermediate structures they inevitably experience value conflicts; experiences that both educate them about the complexities of society and also make them less likely to embrace extreme value positions or ideological movements.

Skocpol (1999) argues that disincentives to extreme viewpoints in a healthy civil society are reinforced by the way in which local membership and community associations are vertically linked to regional and national associations. These latter provide additional links to a variety of information sources and political viewpoints. They also contribute to the building of mediated links between political elites and local levels of citizen involvement (Kornhauser 1959; Skocpol 2003).

When Putnam refers to the erosion of informal ties in Bowling Alone (2000) he seems to mean that there has been a decline in the inclination to participate in community activities and to volunteer. Sociologists have referred to this as a growth in sentiments of 'urbanism' (Wirth 1938). The argument is that when people migrate to cities, lose ties with their home communities of 
origin, move geographically to follow career interests and develop cosmopolitan interests, they tend to volunteer and participate in associations only if doing so serves their immediate self- interest. This tendency has been called 'the community of limited liability' (Strauss 2014,1961).

\section{Are Intermediate Structures Eroding?}

Although there does not seem to have been a decline in formal American volunteering according to publicly available statistics (Bureau of Labor Statistics 2016), there does seem to have been a notable change in the character of civic participation. Main line religion declined during the latter part of the $20^{\text {th }}$ Century and was replaced with a more individualistic, evangelical style of religion (Trueheart 1996). Community-created youth sports have been replaced by professionalized athletic training (Baker, Cobley, and Fraser-Thomas 2009). Community emergency services have been replaced by highly trained, certified emergency response systems (Russo 2001 113-114). Community mutual aid systems have been replaced by government funded, professional social service programs that mandate 'maximum feasible citizen participation' (Walker, McQuarrie, and Lee 2015). Intermediate institutions were once a means through which 'community' could be created and enacted. Socializing, mutual support, and developing a sense of purpose and meaning were their main raison d'etre. Now building community is not a central function of intermediate structures, many of which have become professionalized or subject to market mechanisms of demand and accountability (Walker, McQuarrie, and Lee 2015). 


\section{Explaining the Rise of Trump}

Building on the literature about intermediate structures outlined here, we suggest that one possible explanation for the Presidency of Donald Trump lies in the gradual erosion in the latter part of the $20^{\text {th }}$ Century of crucial elements in the intermediate layer of society; especially those elements that build citizens' social and educational (or what is called 'human') capital (Becker 2009) and encourage active participation in responding to societal problems.

Such an explanation would be in line with both the work of Putnam (op cit.) and the work of Aronowitz (1996). The latter has described how the initial activists in the response to HIV/AIDS melted away from the cause or became grant-funded service providers once responding to AIDS became part of mainstream service provision and mainstream public policy. Selznick (1956) referred to this as a process of 'cooptation' and viewed it positively as an example of how criticism and activism can produce peaceful change. However Aronowitz (1996), like Piven and Cloward (1979), saw the process as negative, undercutting community-initiated change.

The ‘collapse of intermediate structures' explanation for Trump's Presidency would also be in line with writing about the professionalization of community associations and community movements. Skocpol (2003), for example, talks about the professionalization of protest movements like the National Organization for Women in which members pay dues but have no real involvement in formulating or implementing organizational policy. Similarly, many volunteers now find themselves tightly managed by professionals and 
denied the rewards of 'gift relationships' (Titmuss, 1972), which motivate volunteers to give time freely.

So we have several convincing arguments that the intermediate institutions of our society-the structures that have been identified as providing a key support to sustainable democracy-have changed over the last half-century in important ways. We are at the tail end of a process in which the crucial intermediate layer between individual citizens and governmental organizations has changed markedly. Individual citizens have become responsive to appeals to align themselves with powerful politicians and by-pass intermediate structures, which include-most recently-journalists and public commentators. Conversely, we see in Donald Trump, an intense interest in his opportunities to engage personally with citizens rather than through intermediary organizations; an interest reflected most blatantly in the concern he and his team expressed about the actual numbers of people in The Mall at the time of his Inauguration.

In fact, we may have already entered an era foreseen by Dahl and Lindblom (1953) and Aronowitz (1996) in which 'disruptive' forms of political behavior are favored by political elites and individual citizens alike.

\section{Bibliography}

Aronowitz, S. (1996) "Against the liberal state. ACT-UP and the emergence of postmodern politics." Pp 125-144 in The Death and Rebirth of American Radicalism. New York: Routledge. 
Baker, J.; S. Cobley; and J. Fraser-Thomas (2009). "What do we know about early sport specialization? Not much!” High Ability Studies 20: 77-89.

Becker, G. S. (2009). Human Capital. A Theoretical and Empirical Analysis with Special Reference to Education. $3^{\text {rd }}$ Ed. Chicago: University of Chicago Press.

Bureau of Labor Statistics (2016). "Volunteering in the United States." U.S. Bureau of Labor Statistics, Division of Labor Force Statistics, released February 25. Accessed at: https://www.bls.gov/news.release/volun.nro.htm, February 27, 2017.

Cohen, J.L. and A. Arato (1994). Civil Society and Political Theory. Cambridge, MA: MIT Press.

Coleman, J.S. (1994). "Social Capital in the Creation of Human Capital", American Journal of Sociology Supplement, 94, S95-S120.

Coser, L. (1956). The Functions of Social Conflict. New York: The Free Press.

Dahl, R.A. and C.E. Lindblom (1953). Politics, Economics, and Welfare. New York: Harper and Brothers.

Durkheim, E. (1958). Professional Ethics and Civic Morals. Glencoe, IL: The Free Press.

Edwards, M. (2014) Civil Society Cambridge, UK: Polity

Fung, A. (2003). “Associations and Democracy: Between Theories, Hopes, and Realities.” Annual Review of Sociology 29: 515-539.

Kornhauser, W. (1959). "Structure of mass society.” Pp. 74-101, Ch. 3 in W. Kornhauser, The Politics of Mass Society. New York: Free Press.

Meyerson, M. and E.C. Banfield (1955). Politics, Planning, and the Public Interest; The Case of Public Housing in Chicago. Glencoe, IL: Free Press. 
Piven, F. F. and Cloward, R. A. (1979), Poor People's Movements. Why They Succeed, How They Fail. New York: Vintage Books.

Putnam, R., D. (2000). Bowling Alone: The Collapse and Revival of American Community. New York, London, Simon \& Schuster.

Putnam, R.D. (2015). Our Kids. The American Dream in Crisis. New York: Simon and Schuster.

Russo, D.J. (2001). American Towns: An Interpretive History. Chicago: Ivan R. Dee.

Selznick, P. (1966), TVA and the Grassroots. A Study in the Sociology of Formal Organization. New York: Harper and Row.

Silva, J. (2013). Coming Up Short. Working-Class Adulthood in an Age of Uncertainty. New York: Oxford University Press.

Simmel, G. (1955). Conflict and the Web of Group Affiliations. Trans. Kurt Wolff. Glencoe, IL: The Free Press of Glencoe.

Skocpol, T. (1999). "How Americans became civic.” Pp. 27-80, Ch. 2 in T. Skocpol, T. and M.P. Fiorina (eds.). Civic Engagement in American Democracy. Washington, D.C.: Brookings Institution Press. New York: Russell Sage Foundation.

Skocpol, T. (2003). "What We Have Lost", Ch. 6, pp 221-253 in Diminished Democracy. Norman: University of Oklahoma Press.

Strauss, A.L. (2014/1961). Images of the American City. Piscataway, NJ: Transaction. Titmuss, R. M. (1972). The Gift Relationship. From Human Blood to Social Policy. New York: Vintage.

Trueheart, C. (1996), "Welcome to the Next Church," Atlantic Monthly, (August) pp 3758. 
Walker, E.T.; M. McQuarrie; and C.W. Lee (2015). "Rising participation and declining democracy.” Ch. 1, pp. 3-26 in C.W. Lee, M. McQuarrie, and E.T. Walker, Democratizing Inequalities. Dilemmas of the New Public Participation. New York: New York University Press.

Warner, W.L. and P.S. Lunt (1942). The Status System of a Modern Community. New Haven: Yale University Press.

Warren, R. L. (1967), "The Interorganizational Field as a Focus for Investigation," Administrative Science Quarterly, 12: 396-419.

Wirth, Louis (1938). "Urbanism as a Way of Life," American Journal of Sociology 44, 324. 